\title{
THE WEATHER OBSERVATIONS OF SURGEON MENZIES
}

\author{
J. Malcolm Walker * \\ Royal Meteorological Society, Reading, UK
}

\section{INTRODUCTION}

Born in Scotland at Styx (or Stix) House near Aberfeldy in Perthshire (baptised on 15 March 1754), Archibald Menzies was educated at the local Parish School in Weem and thereafter became a gardener at nearby Castle Menzies. He moved some years later to Edinburgh, where he studied botany at the Royal Botanic Garden and trained as a surgeon at the city's University. After taking his degree in medicine in 1781, he practised for a short time in Caernarvon before entering the Royal Navy as an assistant surgeon. He served aboard the Nonsuch under Captain Truscott and on 12 April 1782 witnessed Admiral Rodney's victory over the Comte de Grasse in the Battle of the Saints off Dominica.

He joined HMS Assistance in early 1783 and served for three years on the Halifax Station, where he was able to pursue his interest in botany. From Halifax on 30 May 1784, he wrote the first of his many letters to Sir Joseph Banks, the President of the Royal Society and unofficial Director of the Royal Gardens at Kew. With the letter, he sent seeds he had collected that year, some near New York, others in the West Indies. He was formally introduced to Banks in England in August 1786 and for a few weeks occupied himself in studying the great man's herbarium at Sir Joseph's house in London. He also visited Kew Gardens, where the seeds he had sent from Halifax were now growing.

Menzies did not remain in England for long, for he was appointed surgeon aboard the Prince of Wales in September 1786 and set off soon afterwards on a fur-trading voyage of discovery to the north-west coast of America. During this voyage, of almost three years, he completed his first circumnavigation and devoted his spare time to botany. He returned home with many seeds and plants for Kew and during the voyage sent more than a hundred specimens to Banks, complete with descriptions of the localities where they had been found, identities so far as he could establish them and details of habitats.

\footnotetext{
* Corresponding author address: J. Malcolm Walker, Education Resources Manager, Royal Meteorological Society, 104 Oxford Road, Reading, RG1 7LL, UK e-mail: education@rmets.org.
}

\section{VANCOUVER'S VOYAGE}

In the autumn of 1790, Menzies was appointed naturalist aboard the sloop Discovery for a voyage of exploration commanded by George Vancouver, an experienced seafarer who had served as a midshipman under Captain Cook and now been assigned three tasks by the British Admiralty: to explore the Pacific coasts of North America which were still uncharted; to find a North-West Passage or disprove its existence; and to oversee the return of the British territory and property which had been taken over by the Spanish at Nootka.

The original intention was that Menzies would be a supernumerary, serving only as naturalist. By the time Discovery sailed, however, on 1 April 1791, he had been engaged additionally as an assistant surgeon; and, in September 1792, when the surgeon aboard Discovery became so ill that he had to return home, Menzies was appointed in his place. Vancouver commended his services, stating in the preface to his journal of the voyage that not one man died of ill health under his care.

For the voyage, Menzies was given (by Banks) detailed and extensive instructions (reproduced by Balfour, 1945). He was to investigate as fully as possible the natural history of the countries visited, enumerate all trees, shrubs, plants, grasses, ferns and mosses by their scientific names as well as the language of the natives, and, in view of the prospect of sending out settlers from England, ascertain whether plants cultivated in Europe were likely to thrive. He was to dry specimens and collect seeds; and any curious or valuable plants which could not be propagated from seeds were to be dug up and planted in the glass frame provided for the purpose aboard Discovery.

Menzies was required to keep a regular journal of all occurrences, together with a complete collection of specimens of animals, vegetables and minerals, as well as clothes, arms, implements and manufactures of the native peoples. His work on the voyage was considered by the British government one of the most important objectives of Vancouver's expedition.

Vancouver and Menzies were usually on good terms, though conflicts sometimes arose, the 
most serious being in 1795, when Vancouver moved to have Menzies court-martialled.

On this occasion, the dispute centred on the welfare of plants in the glass frame, which was situated on the quarter deck. The man Menzies considered responsible for looking after the plants failed to cover the frame during a rain storm (which occurred on 27 July 1795). Many plants perished and Menzies was understandably less than best pleased. The plants had been collected with great difficulty and were at that time irreplaceable. Menzies accused the man of negligence but Vancouver, an irascible man at the best of times, flew into a rage, pointing out that he had authorised the attendant's employment on other duties.

The quarrel escalated rapidly, with past disagreement heaped upon past disagreement. Eventually, Vancouver demanded in writing that Menzies hand over his journals, charts and drawings. In so doing, he was, in fact, well within his rights, because he had been instructed by the Admiralty before the voyage began that he should impound all journals and logs prepared by the officers, petty officers and gentlemen on board Discovery (Olson, 1993). Menzies had not known of this at the beginning of the voyage but had come to know of it and become so concerned about it that in April 1795 he had written thus to Banks: "When the journals of the voyage \&c are demanded by Captain Vancouver, I mean to seal up mine, \& address them to you, so that I hope you will receive them".

When ordered to hand over the material, Menzies refused to surrender anything other than the Sick Book and consequently found himself under arrest for insolence and contempt. As soon as he could, Vancouver reported the matter to his superiors; and on 21 September he received orders for the court-martial. At the beginning of October, however, when Discovery returned to the Thames, reason prevailed. Menzies apologised, and on 24 October Vancouver withdrew his demand for a court-martial. On 3 November, Menzies was officially discharged as surgeon of Discovery.

Irreplaceable meteorological records might have been lost for ever had Menzies obeyed Vancouver's order to hand them over. But they came close to being lost for another reason.

\section{THE METEOROLOGICAL CHARTS OF ARCHIBALD MENZIES}

When the Royal Meteorological Society moved its headquarters from London to Bracknell in 1972, the staff did not carry out a thorough 'sort and retain' operation of the Society's archives.
They discarded many old papers and records of the Society.

These documents came into the possession of a London bookseller who offered to return them to the Society, thinking that they may have been discarded unintentionally. No interest was, however, shown in recovering them, whereupon the bookseller offered them for sale, the purchaser being the Harry Ransom Humanities Research Center of the University of Texas at Austin.

Not until the late 1980s, when a catalogue prepared by the bookseller came to light, did the full extent of the Society's loss become known. The papers and records dated back to the late $18^{\text {th }}$ century and included material relating to the United Kingdom's earliest meteorological societies, both called the Meteorological Society of London, one founded in 1823, the other in 1848 (see Walker, 1993). They also included the early papers and records of the present Society, founded in 1850.

For the Royal Meteorological Society, the story had a happy ending, because the Harry Ransom Humanities Research Center generously sold the material back to the Society in 1993.

Among the material recovered was an envelope which contained, in the words of the bookseller's catalogue:

Memoranda as to temperature etc. made by Dr Alex [a mistake for Archibald] Menzies during Vancouver's historic voyage round the world 1791-5. Menzies accompanied Vancouver on this voyage as naturalist, and the plants collected by him were arranged in the sheets containing these notes.

The envelope was addressed to Dr H.R. Mill, a giant of geography and meteorology in the early $20^{\text {th }}$ century.

The words in the catalogue had been taken verbatim from a note attached to the memoranda. It continued as follows:

The sheets were given to me by Mr William

Carruthers, Keeper of Botany in the British Museum, May 1894.

The note was signed by C.E. Fagan and dated June $11^{\text {th }}$ 1907; and Fagan gave as his address "Natural History Museum, London: SW".

When the sheets were inspected on their return from Texas, they were found to contain hundreds of tiny fragments of the plants they had once pressed. These fragments were lost when the sheets were photocopied.

The observations began on 1 April 1791, the day Discovery sailed from England, and consisted of readings of barometric pressure, temperature measured by a "thermometer exposed" and 
temperature measured by a "thermometer immersed", plus reports of wind direction, wind strength and current weather. The report for 7 May 1791 was typical (see Figure 1): "Barometer 30.33 [inches], Thermometer exposed 68 $\left[{ }^{\circ} \mathrm{F}\right]$, Thermometer immersed $66\left[{ }^{\circ} \mathrm{F}\right]$, Wind North $^{\text {ly }}$, Meteorological remarks: Light airs \& clear - at anchor at Teneriff".

As Figure 1 shows, Menzies used descriptions of wind strength very like those proposed by Beaufort in 1806 (see Garbett, 1926). He reported on 25 January 1792, for example, "light airs with intervening calms and rain"; and on 31 January he reported "moderate breezes and cloudy". On other occasions, he reported "fresh breezes", "light breezes", "fresh gales" and "strong gales". The similarity of terminology suggests that Beaufort's descriptions were already used by seafarers in the early 1790s.

From Teneriff (i.e. Tenerife), Vancouver sailed on to the Cape of Good Hope, Australia and New Zealand. On 23 November 1791, when 200 km south-west of New Zealand's South Island, Menzies included the remark "Discovered the Snares", giving their position as $48^{\circ} 03^{\prime} \mathrm{S}$ $166^{\circ} 20^{\prime} \mathrm{E}$, which showed commendably good reckoning, for the co-ordinates are now known to be $48^{\circ} 02$ 'S $166^{\circ} 35^{\prime} \mathrm{E}$. From New Zealand, Vancouver sailed on across the Pacific to Tahiti, Hawaii and the west coast of North America, where he arrived on 17 April 1792. Thenceforth until December 1794, Vancouver charted the coasts all the way from Alaska to Baja California and spent part of each winter in Hawaii. He returned home via Cape Horn. For a full account of Vancouver's voyage, see Lamb (1984).

On most days, especially when Discovery was at sea, meteorological observations were made and recorded. However, the weather records are by no means complete and one wonders if the missing observations may be recorded on sheets still in London's Natural History Museum.

Curiously, readings of barometric pressure ceased abruptly on 7 November 1793 and the reason has not yet come to light. We know that a barometer was broken on 14 March 1794 because Menzies recorded in his journal:

When we got a little out from the Island of Oneehow we experienced a fresh breeze, accompanied by a disagreeable rough \& high sea, which was the occasion of breaking the Marine Barometer in the Cabin - an irreparable loss during the remainder of the voyage.

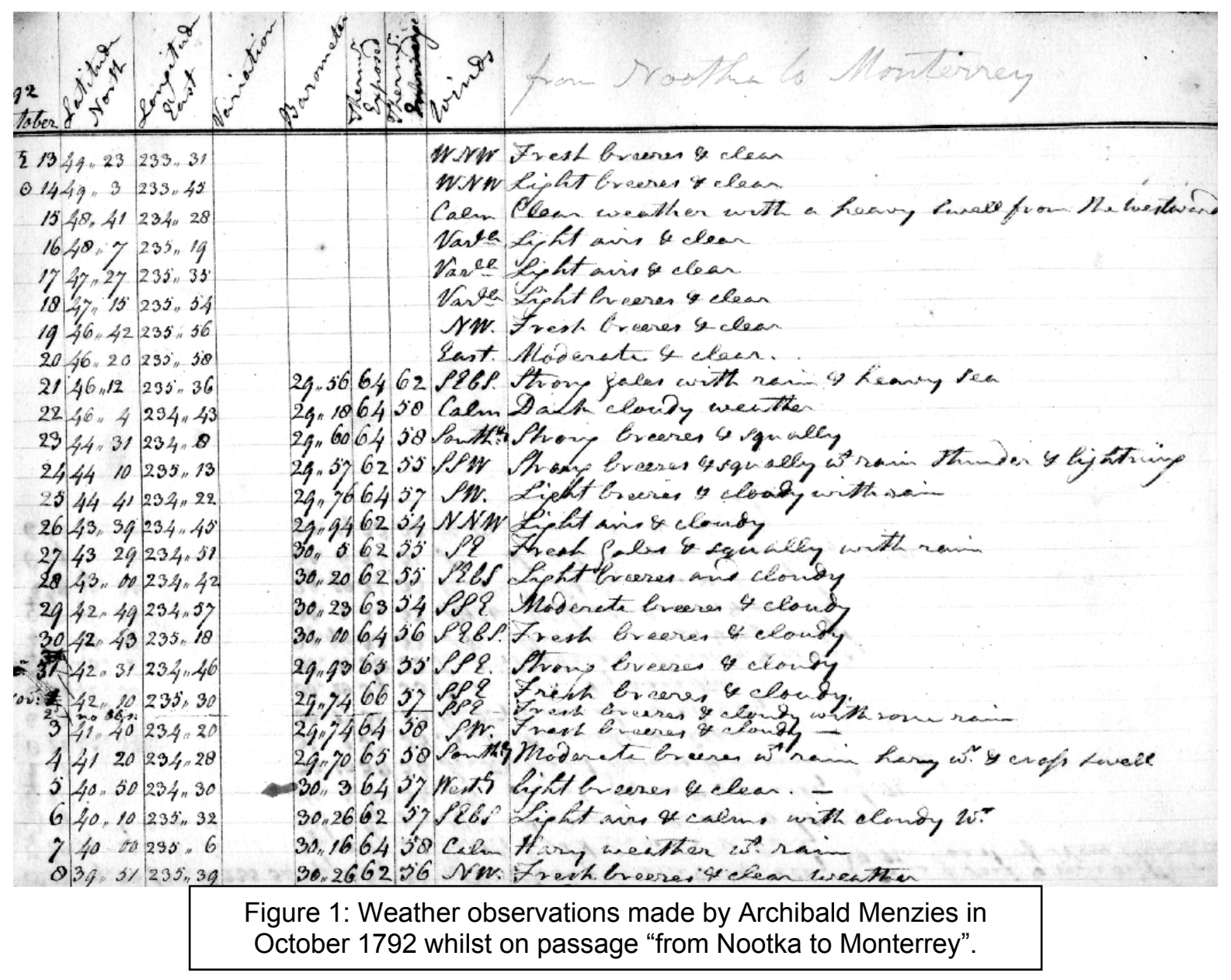

The weather observations of Surgeon Menzies 
Why the readings of barometric pressure ceased four months earlier is not, however, recorded. Menzies was certainly not without a barometer, for he made good use of two in January and February 1794, as we see in Section 4.

\section{MENZIES IN HAWAII}

In January and February 1794, Menzies ascended two volcanoes in Hawaii, Wha-ra-rai and Mauna Loa. For this expedition, he was accompanied by a lieutenant, two midshipmen, a number of gentlemen of the quarter-deck and an American gentleman who had recently arrived in Hawaii from China.

To ascertain the heights of the volcanoes, Menzies used a barometer. This was, he said (Menzies, 1828):

A kind of portable barometer, for which I was entirely indebted to the liberality of the late Colonel Gordon at the Cape of Good Hope. That gentleman, when he understood that we had no portable barometer on board for ascertaining the height of any mountain that might be ascended during the voyage, presented me, in the most generous manner, with his own, which he had long been in the habit of using in the interior parts of Africa.

Of the merits of this instrument, Menzies (op.cit.) wrote as follows:

The simplicity of its contrivance, and the ease with which it is carried and managed, may probably render it preferable, on such occasions, to a more expensive instrument, which, in ascending pathless rugged mountains, is so liable to be broken. I shall, therefore, subjoin a short description of it, and the manner of using it, leaving the reader to judge the probable degree of accuracy of the observations made with it at different heights, both in this and in my subsequent journey to the summit of Mowna-roa [Mauna Loa].

From his readings of barometric pressure, Menzies estimated the height of the summit of Whara-rai to be 8,457 feet above sea level. He and his companions remained on the top of the volcano for two days (19 and 20 January), finding the pressure there to be 22.40 inches one day and 22.44 inches the other (see Menzies, 1829). He took the mean of these two readings and subtracted it from the pressure at sea level, 30.16 inches, measured simultaneously on board Discovery. From the difference, 7.74 inches, he calculated the height of the mountain.

He did the same for Mauna Loa, estimating its height (from the pressure readings he made on its summit on 16 February) to be 13,634 feet above sea level. This was a remarkably accurate figure, for the height today is considered to be 13,680 feet.

In Vancouver's account of his round-the-world voyage (Lamb, op.cit.), there is only the briefest mention of the ascents of the volcanoes made by Menzies and his companions. The reason may have been that Vancouver was annoyed with Menzies for his late return to Discovery several days late, indeed. Whatever the reason for the brevity of the reference, nothing can diminish the achievements of Menzies and his companions. Not only did they use a barometer to estimate the heights of the volcanoes; they were also the first Europeans to climb Mauna Loa. Quite possibly, in fact, they were the first from anywhere to climb it, given that the indigenous people were reluctant to venture above the snow line.

\section{CONCLUDING REMARKS}

The weather diary kept by Archibald Menzies during Vancouver's historic voyage of 1791-95 is important historically for a number of reasons, not least because it includes the first weather observations made systematically along the west coast of North America, including some made at San Francisco, San Diego and Monterey.

After Vancouver's voyage, Menzies remained in the navy for several years before retiring and then practising as a surgeon and pursuing his interest in botany. "As the years passed", as Keevil has put it, "Menzies became an increasingly venerated figure in the scientific world". He received a number of honours, including an honorary doctorate of medicine from the University of Aberdeen in 1799 and the Diploma of the University of Leipzig in 1822. He married late in life and had no children. His wife died in 1836 and he passed away six years later, on 15 February 1842.

\section{REFERENCES}

Balfour, F.R.S., 1945. Archibald Menzies, 17541842, Botanist, Zoologist, Medico and Explorer. Proc. Linnean Society, $156^{\text {th }}$ Session (1943-44), Part 3, 170-183.

Garbett, L.G., 1926. Admiral Sir Francis Beaufort and the Beaufort scales of wind and weather.

Q.J.R.Met.S., 52, 161-172. See also:

http://www.metoffice.gov.uk/education/ historic/beaufort.html, a web-page written for the UK Met Office by the present author.

Keevil, J.J., 1948. Archibald Menzies, 17541842. Bulletin of the History of Medicine, 22, 796-811. 
Lamb, W.K. (Ed.), 1984. A voyage of discovery to the North Pacific Ocean and round the world 1791-1795 by George Vancouver, with an Introduction and Appendices. In four volumes. The Hakluyt Society, London.

Menzies, A., 1828. Some account of an ascent and barometrical measurement of Wha-ra-rai, a mountain in the Island of Owhyhee; extracted from the MS. journal of Archibald Menzies, Esq., F.L.S. Magazine of Natural History, 1, 201-208.

Menzies, A., 1829. Some account of an ascent and barometrical measurement of Wha-ra-rai, a mountain in the Island of Owhyhee; extracted from the MS. journal of Archibald Menzies, Esq., F.L.S. Magazine of Natural History, 2, 435-442.

[F.L.S. = Fellow of the Linnean Society. This society was founded in 1788 and Menzies was elected a Fellow in January 1790.]

Olson, W.M., 1993. The Alaska travel journal of Archibald Menzies, 1793-1794, with an introduction and annotation by Wallace $\mathrm{M}$. Olson and a list of the botanical collections of John F. Thilenius. University of Alaska Press, Fairbanks.

Walker, J.M., 1993. The Meteorological Societies of London. Weather, 48, 364-372.

\section{FURTHER READING}

Eastwood, A. (Ed.), 1923-1924.

Menzies' California journal. California Historical Society Quarterly, 2, 265-340.

Fisher, R., 1992. Vancouver's voyage: charting the northwest coast. University of Washington Press, Seattle, 131 pages. 